\title{
Architektura ogrodów zimowych otwarta na światło słoneczne
} Architecture of winter gardens open to sunlight

\begin{abstract}
Streszczenie
Artykuł prezentuje rolę i znaczenie ogrodów zimowych w kształtowaniu współczesnej zabudowy mieszkaniowej, a także współczesne ich koncepcje towarzyszące zabudowie mieszkaniowej wraz z ich estetyką i rozwiązaniami technologicznymi na tle ewolucji ich formy architektonicznej na przestrzeni wieków. Renesans ogrodów zimowych zaznaczył się szczególnie w ostatnich dekadach wraz z rozwojem idei architektury proekologicznej i zrównoważonej.
\end{abstract}

\begin{abstract}
The article presents the role and meaning of winter gardens in the process of shaping the contemporary residential architecture, as well as their contemporary concepts accompanying residential architecture along with their aesthetics and technological solutions against the background of the evolution of their architectural form over centuries. The renaissance of winter garden was particularly vivid in recent decades, with the development of pro-eco and sustainable architecture.
\end{abstract}

Słowa kluczowe: architektura, architektura ekologiczna, ogród zimowy, światło słoneczne

Keywords: architecture, ecological architecture, winter garden, sunlight

\section{Wprowadzenie}

Celem pracy jest zaprezentowanie roli oraz bogactwa form ogrodu zimowego jako miejsca służącego kontaktowi człowieka ze światłem słonecznym oraz zielenią. Współczesne realizacje omawiane są na tle ewolucji tych transparentnych, powiązanych z budynkami wnętrz. Uzasadnione jest to kontynuacją wielowiekowej tradycji w powstających obecnie rozwiązaniach architektonicznych, a także ich atrakcyjnością, niezależnie od epoki w jakiej powstawały.

Wznoszenie ogrodów zimowych umożliwiło pojawienie się, uznawanego zawsze za niezwykły i zmieniający całkowicie charakter architektury, materiału jaki stanowiło szkło i stały rozwój oraz doskonalenie technologii jego wytwarzania1. Jako energooszczędne, przyjazne mieszkańcom i środowisku rozwiązania przeżywają obecnie renesans i wprowadzane są powszechnie we współczesnych koncepcjach architektury proekologicznej i zrównoważonej.

Zaletą łączenia tych szklanych, klimatycznych stref z zabudowę mieszkaniową jest możliwość użytkowania ich jako dodatkowego pokoju rekreacyjnego (zielona izba) przy jednoczesnym pełnieniu przez nie roli elementów helioaktywnych (efekt szklarniowy) w koncepcji pozyskiwania energii słońca na zasadach pasywnych. Odpowiada to najstarszym, znanym od tysiącleci, prostym i wpisującym się w klimat, technikom budowania. Opierały się na założeniu, że architektura, choć nie stanowi elementu przyrody, podlega oddziaływaniu takich

\section{Introduction}

The goal of this paper is to present the role and the richness of forms of a winter garden as a place fostering the contact of man with sunlight and greenery. Contemporary projects are discussed against the background of the evolution of these transparent interiors, inseparably linked to buildings. It is justified with the continuation of an ages-long tradition in architectural solutions that are created now, as well as their attractiveness, irrespectively from the epoch when they came into being.

Construction of winter gardens was made possible thanks to the occurrence of a new material, always recognised as a unique one, completely changing the character of architecture, namely glass, as well as the constant development and improvement of the technology of its production'. Regarded as energy-efficient, user and environment friendly solutions, they are experiencing a renaissance today and are commonly introduced to contemporary concepts of pro-eco and sustainable architecture. The advantage of combining these glass climatic zones with residential development is the possibility of utilising them as an additional recreational room (a green room), while at the same time they fulfil the role of helio-active elements (greenhouse effect) in the concept of harvesting solar energy according to the principles of passivity. It corresponds to the oldest building methods, known for millennia, simple and adequate to the local climate. They were based on an assumption that architecture, although it does not constitute an element of na- 
samych zewnętrznych czynników jak wszystkie organizmy naturalne, m.in. działaniu swiatła słonecznego, wody, wiatru. Należy podkreślić, że wprowadzająca ogrody zimowe architektura mieszkaniowa odznacza sie wiekimi walorami estetycznymi mas łączy ona logike i piękno w sposób wyjątkowy². Ocenę tę potwierdzaja zaprezentowane niżej przykłady historyczne, a także współczesne realizacje, które kontynuują wielowiekowe tradycje. Wiedza i doświadczenia poprzednich generacji stanowią inspirację i podstawę dla twórczej aktywności współczesnych projektantów oraz poszerzają jej pole o nowe możliwości.

2. Ewolucja form ogrodów zimowych - rys historyczny Europejska tradycja wznoszenia ogrodów zimowych sięga czasów starożytnego Rzymu, który rozwinął greckie osiągnięcia w zakresie ksztaltowania budynków w powiązaniu z klimatem i miejscem (Witruwiusz). Momentem przełomowym stało się pojawienie, już w I wieku n.e., nowych, transparentnych materiałów - płaskiego i wypukłego szkła oraz miki, selenitu i marmuru w celu krycia okien, a także dziedzińców3. Pozwoliło to na wprowadzanie światła słonecznego do wnętrz mieszkalnych i korzystanie z prostego zjawiska efektu cieplarnianego w celu ich ogrzewania4. U progu pierwszego tysiąclecia pojawiły się też pierwsze szklarnie do upraw egzotycznych roślin, owoców i warzyw. Ogrody zimowe wprowadzane byly tez do miejskich domów i willi w celach dekoracyjnych ${ }^{5}$. lch przeszklone wnetrza służyły jako pułapka dla ciepła słonecznego, a doświadczenia z ich konstruowaniem weszły do zbioru, aktualnych do dzisiaj, podstawowych zasad kształtowania obiektów pozyskujących energię słońca w sposób pasywny.

Wraz z upadkiem imperium rzymskiego zanikła w Europie na ponad tysiąc lat tradycja budowy oranżerii i cieplarni. Pojawiły się dopiero w XIII wieku we Włoszech, a na szersza skalę zaczęto wprowadzać je na północ od Alp w okresie renesansu $^{6}$. Poczatkowo stosowano jedynie sezonowe, drewniane i rozbierane, wypełniane szkłem konstrukcje wznoszone nad roślinami?.

Doskonalenie metod produkcji szkła pozwoliło na rozwój tych niezwykłych obiektów w postaci stałych budowli o atrakcyjnych oraz różnorodnych formach ${ }^{8}$. Służyły przechowywaniu w okresie zimowym przede wszystkim drzew cytrusowych i egzotycznych roślin, a posiadanie ich stało się symbolem szczególnego statusu materialnego właścicieli.

Około połowy XVI wieku pionierami w konstruowaniu ogrodów zimowych, na ogół w postaci długich i wąskich hal, o dużych przeszklonych, południowych oknach i pełnych dachach stali sie Holendrzy i Flamandowie (il. 1 a b). Doświadczenia te kontynuowały kolejno Anglia, Francja i Niemcy'. Wraz z doskonaleniem konstrukcji oranżerie zaczęły przyjmować rolę reprezentacyjnych budowli' ${ }^{10}$. Powstawały jako obiekty o zróżnicowanej wielkości, o różnych zasadach ogrzewania, wietrzenia i zacieniania w dostosowaniu do wymogów roślin, dla ture, is subjected to interactions with the same external factors as all natural organisms, e.g. sunlight

water, wind.
It should be emphasised that residential archigreat aesthetic values, as well as a unique quality and style. It is believed that it combines logic an beauty in quite a remarkable way². This evaluatio is confirmed by the historical examples presented below, as well as contemporary projects, which continue the age-long traditions. The knowledge and experience of the previous generations con-
stitute an inspiration and a foundation for creative activities of contemporary designers, and they extend its field with new opportunities.

2. Evolution of forms of winter gardens - histor

The European tradition of erecting winter gardens Greek achievements in terms of designing buildings in connection with the surrounding climate and specific location (Vitruvius). A moment which marked a true breakthrough in this respect was the occurence - as early as in the $1^{\text {st }}$ century A.D. - of new transparent materials. flat and convex glass, as well as mica, selenite, and marble used for covering win-
dow openings and internal courtyards s. It allowed $^{2}$. to introduce sunlight to residential premises and to make use of a simple phenomenon of the greenhouse effect in providing heating ${ }^{4}$. At the threshold of the first millennium, the first greenhouses appeared, too, enabling to grow exotic plants, fruit and vegetables. Winter gardens were also introduced to Their glazed interiors trapped sunlight, and the experience deriving from building them entered the collection of basic rules - still valid - of designing buildings harvesting energy of the sun according to the principles of passivity.

The fall of the Roman empire caused a decline of the tradition of building conservatories and greenappeared as late as in the $13^{\text {th }}$ century in Italy $r$ they were started to be introduced to the north from the Alpes on a larger scale in the period of Renaissance $e^{6}$. Initially only seasonal, wooden and disassemblable structures filled with glass were erected over plants

Advancements in the field of glass production alfacilities as buildings with very attractive and diversified forms ${ }^{8}$. They were used most of all for the storage of citrus trees and exotic plants in wintetime, and possessing one was a symbol of a special material status of its owner.

In ca. mid- $16^{\text {th }}$ century the Dutch and the Flemish usually had a shape of long and narrow halls, with large glazes southern windows and full roofs. (ill. a, b). These experiences were subsequently continued by England, France, and Germany'. As the structure was gradually perfected, conservatories started to assume a role of representational buildings ${ }^{10}$. They were erected as buildings of differen ing and shadowing to adjust to the needs of the plants they were intended for ${ }^{11}$. They also started

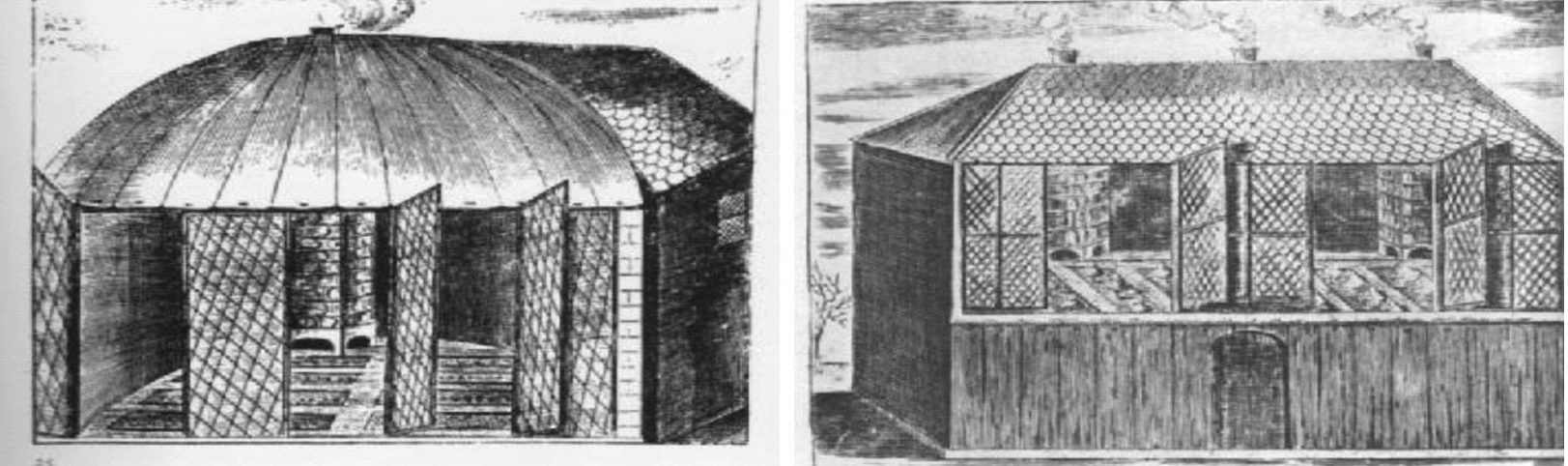

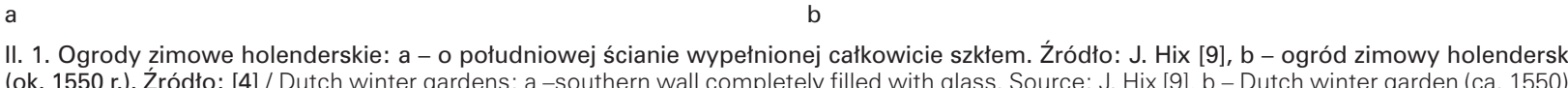
Source: [4]
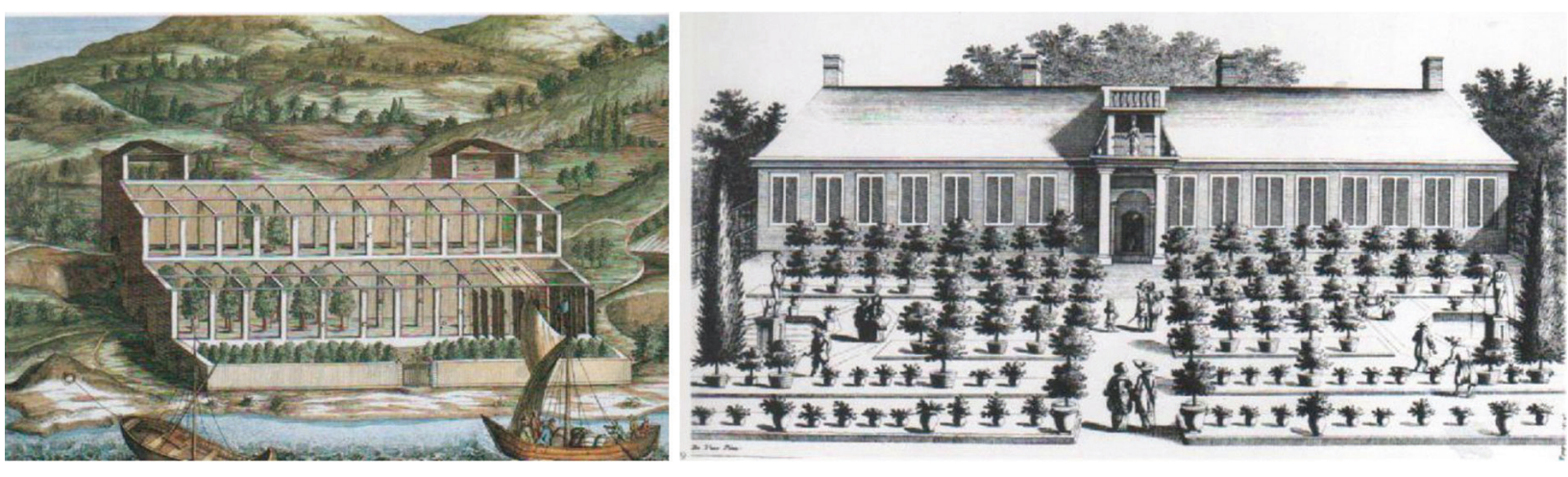

II. 2 Obiekty do przechowywania w zimie egzotycznych drzew, XVII wiek: a - przeszklone konstrukcje w ogrodach botanicznych Aldobrandin

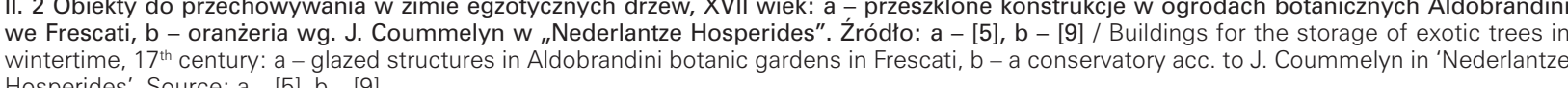

których były przeznaczone1․ Zaczęto je też wznosić dla celów doświadczalnych przy uniwersytetach i w ogrodach botanicznych (m.in. oranżeria w Lejdzie, 1599).

Wiek XVII rozpoczałt, trwający nieprzerwanie i upowszechniający się w całej Europie do końca XIX stulecia, proces wznoszenia ogrodów zimowych oparty na produkcji dużych i wytrzymałych tafli szkła, a także rozwój zróżnicowanych technologii konstrukcyjnych'2 (il. 2). Ich przeszklone kubatury, o południowej ekspozycji, prostym porządku architektonicznym i wielkich walorach estetycznych łączono na ogół z założeniami pałacowymi lub sytuowano $w$ ogrodach jako obiekty wolno stojące (m.in. Wersal, Meudon) $)^{13}$

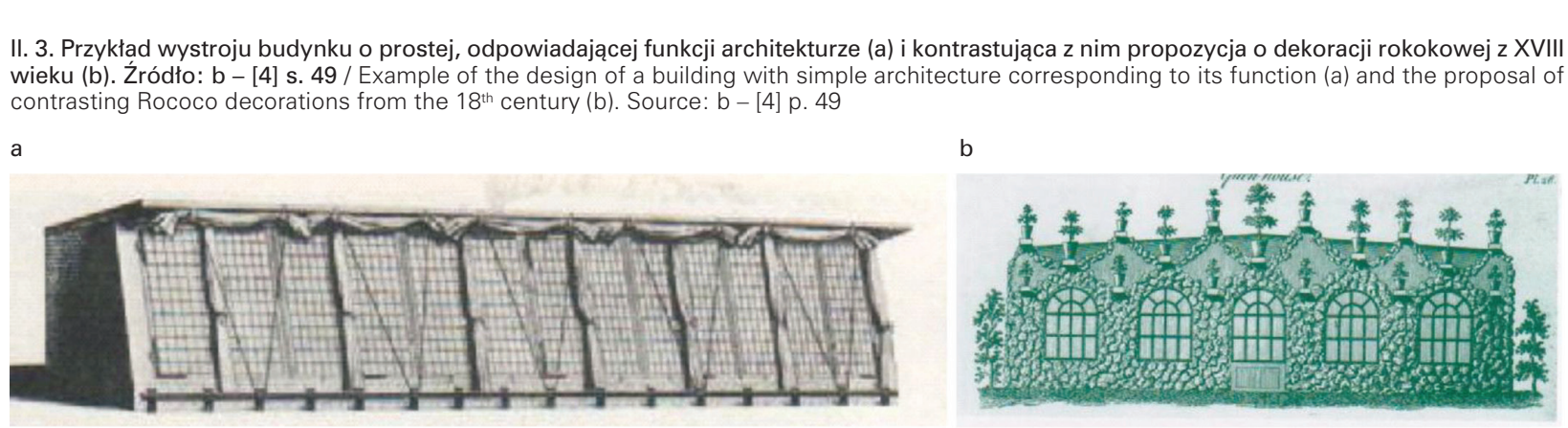

to be erected for experimental purposes at universities and in botanic
tory in Leiden, 1599).

The $17^{\text {th }}$ century marked the beginning of the process of erecting winter gardens based on the production of large and durable glass panels, incessantly present and disseminating on the entire as well as the development of diversified building technologies' ${ }^{12}$ (ill. 2). Their glazed forms, with the southern exposition, a simple architectural order, and enormous aesthetic values were usually combined with palaces or located in gardens as de-

The next $18^{\text {th }}$ century was dubbed the 'Age of the 


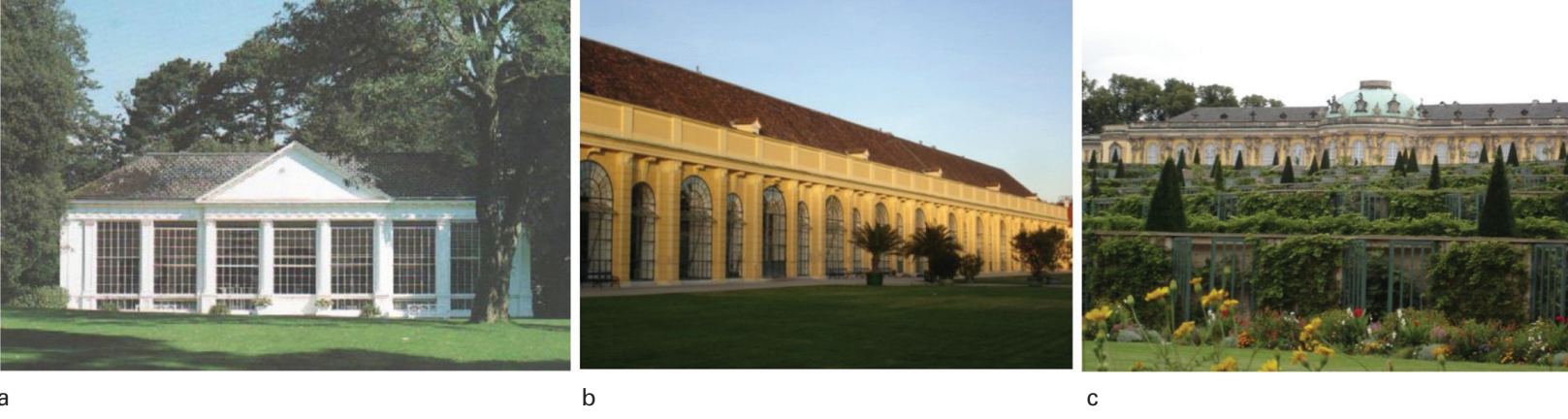

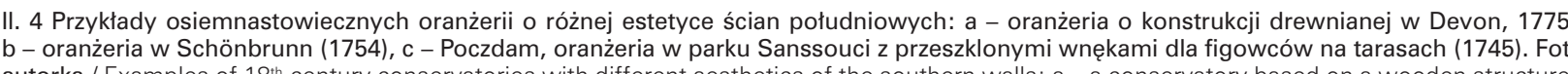

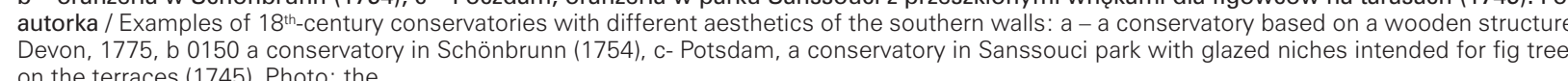

Kolejne stulecie, wiek XVIII, zyskało miano "wieku cieplarni" (Age of the Greenhouse) wskutek powszechnego wprowadzania zarówno oranżerii jak i szklarni dla upraw delikatnych roślin (F. Miller, 1751, H. de Saussure - dowód „efektu cieplarnianego", 1767). Konstrukcja, forma i wystrój wnętrz tych plarnianego", 1767). Konstrukcja, forma i wystrój wnętrz tych obiektów wpisywały się przeważnie we wzory francuskie i ho-
lenderskie (przykład: rokokowa dekoracja z 1768 roku) (il. 3a, b, il. 4) $)^{14}$. W celu lepszego pozyskiwania przez nie światła słonecznego zaczęto też konstruować południowe, nachylone ściany szklane ${ }^{15}$

Wiek XIX, określany jako druga epoka szkła ${ }^{16}$, stanowił okres wielkiego rozkwitu różnych form ogrodów zimowych oraz licznych eksperymentów dotyczących ich konstrukcii, w tym $z$ zastosowaniem stali oraz poszukiwaniem optymalnego kąta nachylenia przeszkleń (m.in. T. Knight, 1811, G. Mackenzie, 1815, J.C. Loudon, 1817) ${ }^{17}$. Występowały w postaci atrakcyjnych, transparentnych wnętrz o różnej skali, powszechnie dodawanych od południa do budynków mieszkalnych lub też w formie okazałych obiektów wznoszonych w ogrodach i parkach ${ }^{18}$.

Szczególną rolę $\mathrm{w}$ promocji idei bezpośredniego łączenia ogrodów zimowych z domem i mieszkaniem odegrał angielski architekt Humphrey Repton (1752-1818)19. Jego realizacje uważane za niezwykle innowacyine, wprowadzaty , salony roślinne" (Pflanzensalon, Blumenzimmer, Wintergarten) doda-

Greenhouse' as a result of the widespread introduction of conservatories, as well as greenhouses for the culivation of delicate plants (F. Miller, 175 , fect', 1767). The structure, form, and interior design of these structures usually corresponded to rations from 1768) (ill. $3 \mathrm{a}, \mathrm{b}$, ill. 4) 4$)^{14}$ In order to secure a better level of daylight harvesting, inclined southern, glass walls started to be popular ${ }^{15}$. The $19^{\text {th }}$ century, dubbed the second glass age ${ }^{16}$, was the heyday of winter gardens and numerous experiments referring to their structure, including the ap-

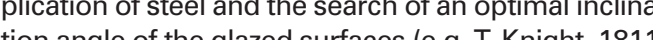
G. Mackenzie, 1815, J.C. Loudon, 1817)17.

They appeared as attractive, transparent interiors in different scales, commonly added to residential bullings from the south, or had a form of magnifiA special role in promoting the concepts. A special role in promoting the concept of direct ment was played by an English architect, phrey Repton $(1752-1818)^{19}$. His projects, regarded as extremely innovative, introduced 'plant salons' (Pflanzensalon, Blumenzimmer, Wintergarten) adding them to houses at the ground floor leve along the entire southern elevation or in the form of smaller elements, e.g. at the corners, as well They were given attractive architectural forms

II. 5 Propozycja przeksztatcenia wnetrza mieszkalnego przez dodanie ogrodu zimowego od potudnia wedtug projektu H. Reptona. Żródto: [4], s. 53
/ Proposal of transforming residential premises by adding a winter garden from the south according to a design by H. Repton. Source: [4], p. 53
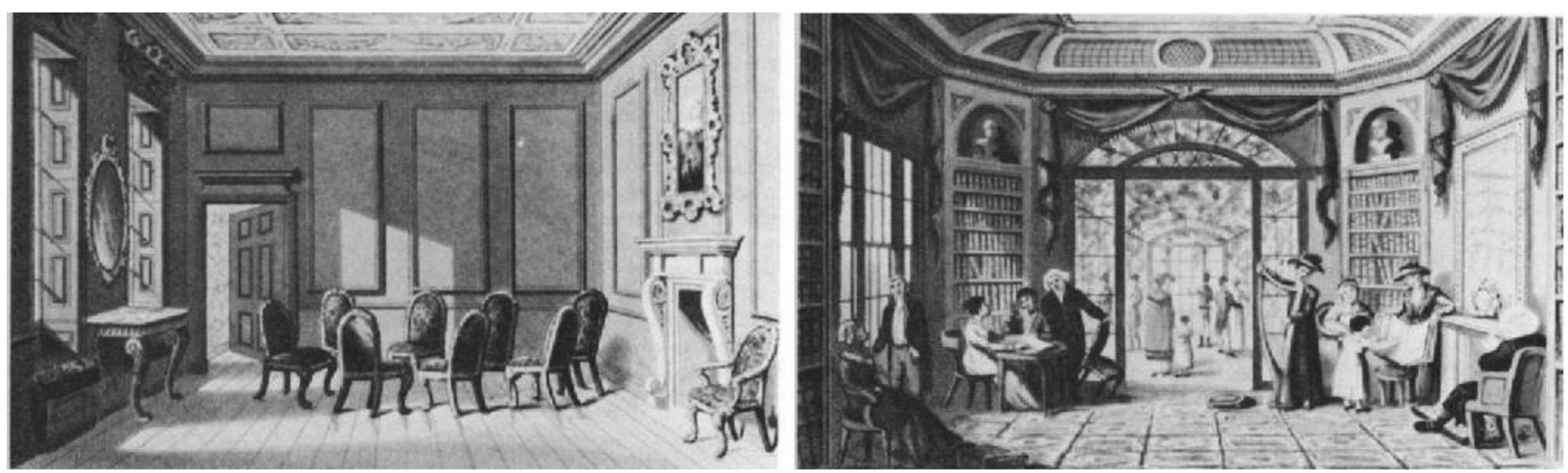
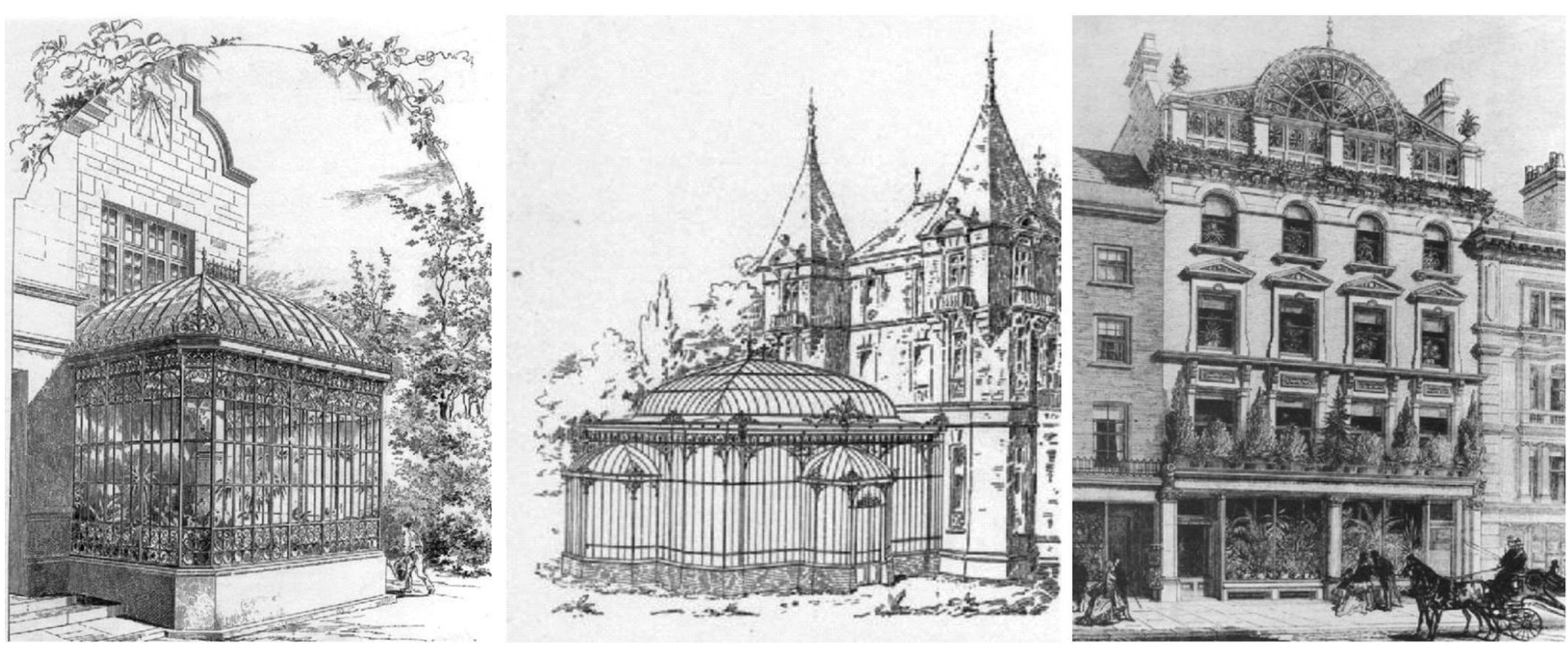

II. 6. Ogrody zimowe potaczone z budynkami mieszkalnymi: a - dom w Paryżu, b - zamek w St.-Hilaire-St.-Florent we Francii, Żródto: [17], c -
kamienica w Londynie, zródto: [4] / Winter gardens combined with residential houses: a - house in Paris, b - castle in St.-Hilaire-St.-Florent, France,
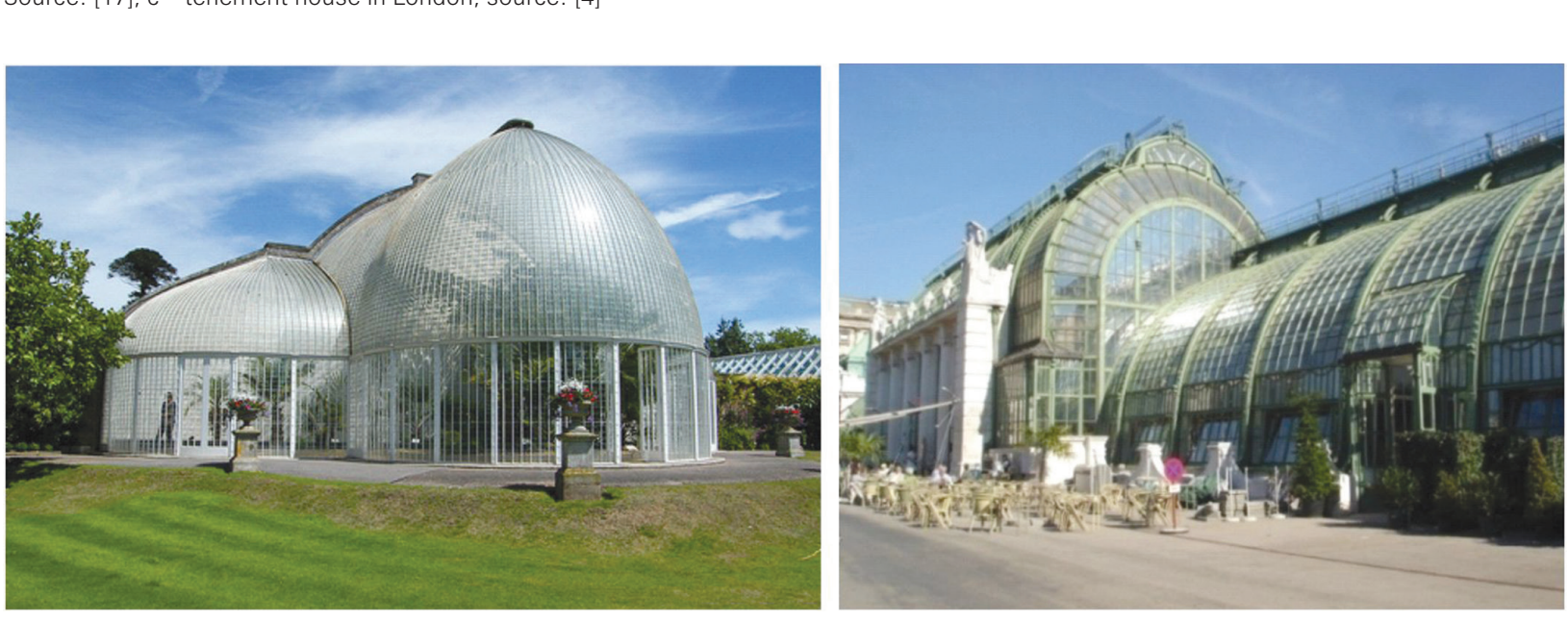

I1. 7. Palmiarnie o prostej, funkcjonalnej formie: a - w Bicton Garden (J. Paxton, 1820. Żródto: [9], b - Hofburg, Wiedeń (1905) Fot. autorka/ Palm

jạc je do domów na poziomie parteru wzdłuż całej południowej elewacji lub też $w$ formie mniejszych elementów, m.in. narożnych, a także sytuując je na wyższych kondygnacjach lub dachach. (II. 5) Nadawano im atrakcyjne formy architektoniczne o różnych krzywiznach, projektowane na rzutach kolistych, prostokątnych i wielokątnych ${ }^{20}$ (il. 6).

Omawiane stulecie przyniosło też rozkwit nowatorskich monumentalnych założeń oranżerii, szklarni, cieplarni (glasshouse) i palmiarni, o wielkich płaszczyznach szklanych scian i dachów, które pojawity sie przy rezydencjach, w otwartych ogrodach publicznych oraz w miejskich park otlch piekno polegato osowanej do funkcji i eksponowaniu przeszklonych płaszczyzn odzwierciedlających nowe technologie szkła i stali epoki rewolucji przemystowej (obiekty m.in. J. H. Paxtona, A. Balata) ${ }^{2}$ (il. 7). Wyjątkowym eksperymentem stał się Crystal Palace (J. Paxton, Londyn, 1851). with different curvatures and they were designed on circular, rectangular, and multi-angular floor plans ${ }^{20}$ (ill. 6 ). novative, monumental designs of conservatories, genormous appeared near manors, in open public gardens, and in municipal parks. Their beauty resided in the simplicity of form adjusted to their function and in exposing glazed surfaces reflecting new echnologies of glass and steel of the industrial

Cinger the con a winter garden in the 20th century

The beginning of the $20^{\text {th }}$ century opened a new, third epoch of glass-related architecture in Europe, within the scheme of the development of modern-
ism, as well as its organic trend. Modernists were
This century brought about an abundance of in(designs by e.g. J.H. Paxton, A.

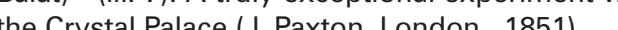




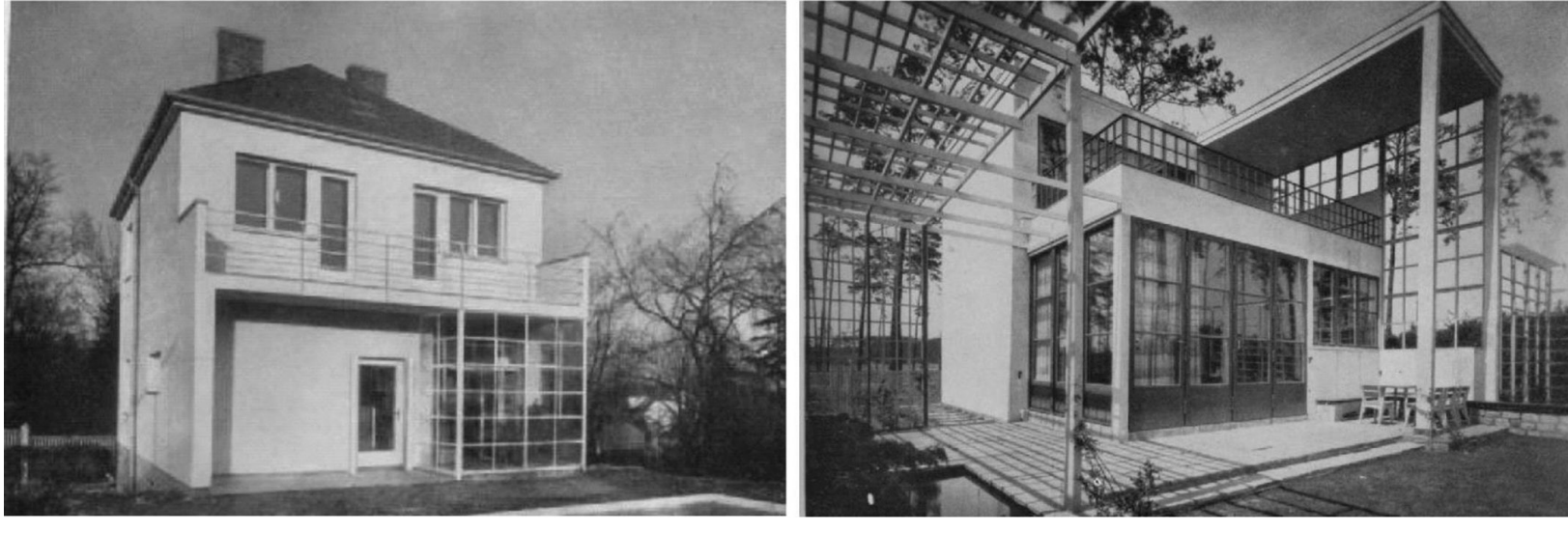

II. 8. Domy jednorodzinne z ogrodami zimowymi usytuowanymi od południa: a - dom w Wiedniu, b - dom w $w$ Berlinie. Żródło: [22] / One-fami-
ly houses with winter gardens located on the southern side: a - house in Vienna, b- house in Berlin. Source: :22]
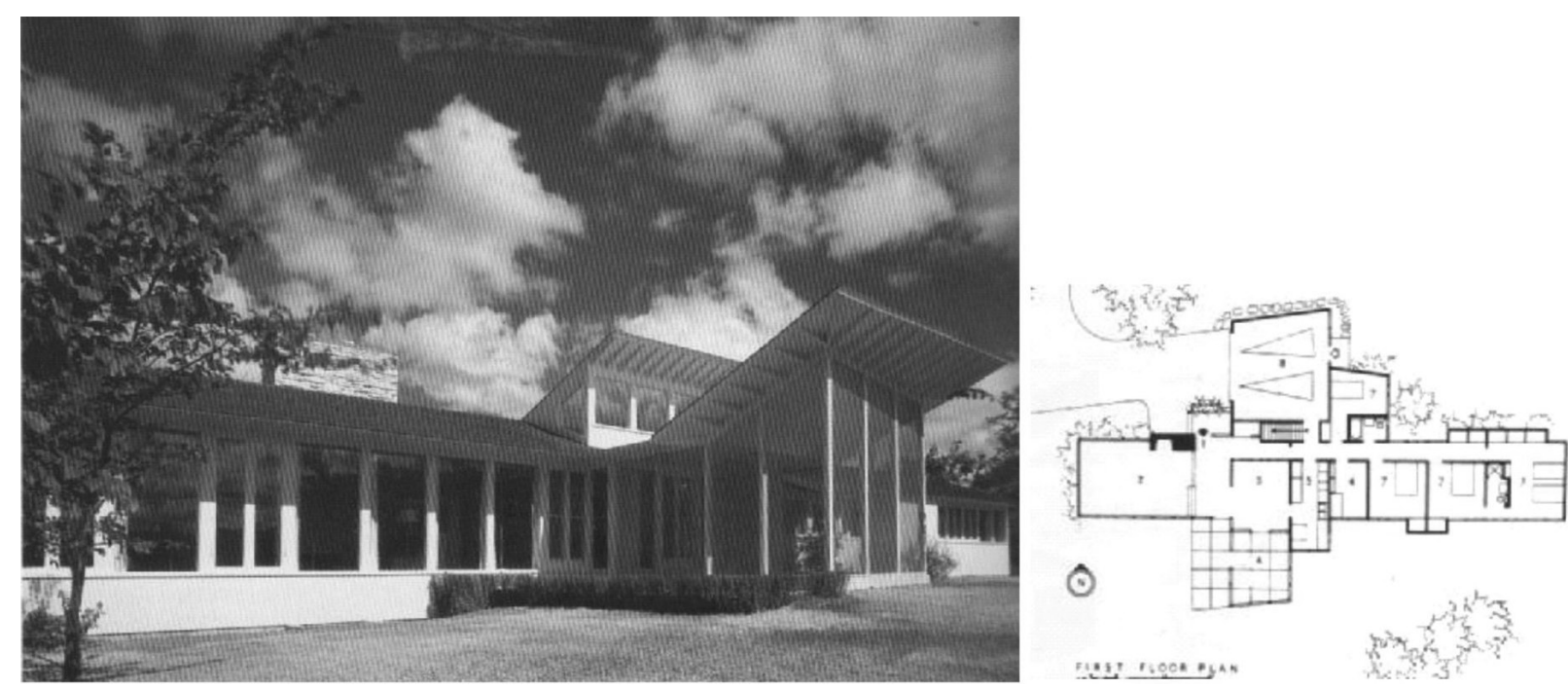

II. 9. Modelowy przykład domu z ogrodem zimowym i szedowym dachem projektu G. F. Kecka dla H. Sloana w Glenview - widok dlugiej,
przeszklonej elewaciji potudniowej i rut domu, 1940 , Zródto: [3], s. $76 /$ A model example of a house with a winter garden and a sawto oth roof
designed by G.F. Keck for H. Sloan in Glenview - view of a long, glazed southern elevation and the floor plan of the house, 1940, Source: [3], p. 76

3. Rozwój koncepcji ogrodu zimowego w wieku XX Początek XX wieku otworzył w Europie nową, trzecią epokę architektury związanej ze szkłem $w$ ramach rozwoju modernizmu, a także nurtu organicznego. Moderniści rozwijali studia przezroczystości w architekturze w oparciu o nowe możliwości produkcyjne tego materiału pozwalające na masowe wytwarzanie dużych jego tafli (pionierzy: B. Taut, P. Scheerbart, A. Sant'Elia, W. Gropius, M. van der Rohe). Otwarte na światło słoneczne społeczne budownictwo mieszkaniowe, podporządkowane wymogom zdrowia i higieny, rozwinęto się szczególnie na szeroką skalę w Niemczech, Holandii, Szwecji i Szwajcarii (ill 8).W Wego ramach ponownie pojawito sie zainteresowanie przesz $z$ przestrzen le Heuberg w Wiedniu, 1921/22) 22 . W Niemczech promowat je L. Migge, który wraz z M. Wagnerem i B. Tautem, rozwijat wizje osiedli o ogrodach zimowych łączonych z apartamentam (Hufeisensiedlung Berlin-Britz, 1925-27)23, a także koncepcje developing their studies devoted to transparency in architecture basing on new opportunities relating to the manufacture of this material, allowing for mas production of large glass panels (pioneers: B. Tau Rohe). Social A. Sant Elia, W. Groplus, M. van der the requirements of health and hygiene, developed particularly well in Germany, Holland, Sweden, and Switzerland. (ill. 8) Within its scheme, the interest in glazed verandas, combined with the space of a house or an apartment, re-appeared (A. Loos and L. Migge, Heuberg housing estate in Vienna, Migge, who together with $M$. Wagner and $B$. Tau was developing visions of housing estates furnished with winter gardens combined with apartments (Hufeisensiedlung Berlin-Britz, 1925-27)'23, as well as concepts of residential houses combined with greenhouses and intensive gardening (e.g. exhib The conaunschweig, 1925 , in Berlinie, 1932). den in architecture' was also promoted by $\mathrm{H}$. Tessenow and $\mathrm{H}$. Muthesius.
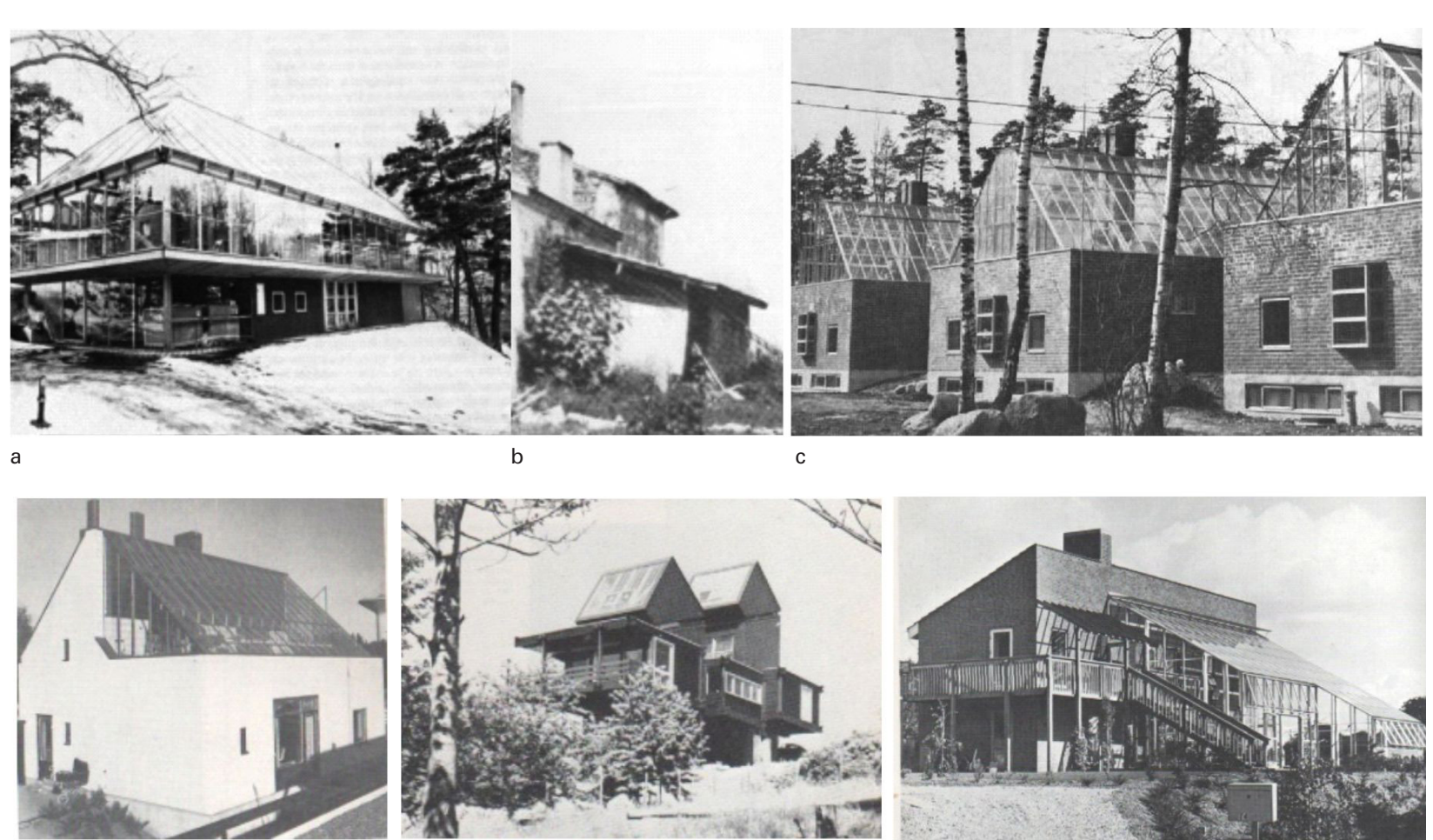

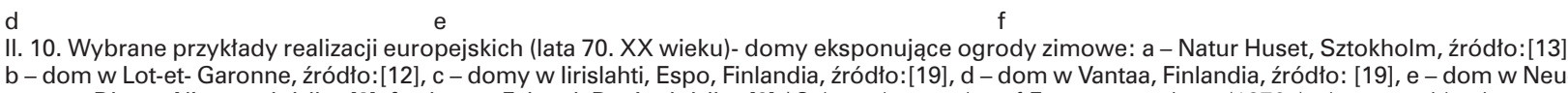
dens: a - Natur Huset, Stockholm, source: [13], b - house in Lot-et - Garonne, source: [12], c - houses in lirislahti, Espo, Finland, source::[19], d - house
in Vantaa, Finland, source::[19], e- house in Neumagen - Dhron, Germany, source: [8], f- house in Felsted, Denmark, source: [6]

domów mieszkalnych powiazzanych ze szklarniami i intensywnym ogrodnictwem (m.in. wystawa w Braunschweig, 192524, w Berlinie, 1932).

dee „architektury w ogrodzie i ogrodu w architekturze" propagował również $\mathrm{H}$. Tessenow i $\mathrm{H}$. Muthesius.

Omawiając rozwój koncepcii ogrodu zimowego w pierwszej polowie XX wieku nie można nie wspomnieć o niezwyklych ańskich architektów - twórców dzieł uznawanych za unikaln w historii architektury mieszkaniowej. Nalezal do nich Artur Brown (dom Rosenbergów, Tucson, Arizona, 1946) i George Fred Keck (The house of Tomorrow, 1933 i The Crystal House, 1934) (il. 9).

Po II wojnie światowej badania dotyczące architektury energooszczędnej, a wraz z nimi także prace i projekty włączajace w przestrzeń domu ogrody zimowe, uległy zahamowaniu. Idee te zaczety odradzać sie ponownie z końcem lat 60. wo w Europie jak i w USA. Do doświadczeń amerykańskich które miały znaczacy wpływ na rozwiazania europejskie, należały prace takich twórców, jak A. Predock, D. Easton, D. Holloway, W. Lumpkins, P. Van Dresser, S. Bear, D. Wright. Rozwijali oni od lat 70. XX wieku rozwiązania nawiązując do tradycji lokalnej architektury bioklimatycznej. Cechowało je szczególne bogactwo i różnorodność koncepcji, a takż funkcjonalnośc i ekonomia, logika oraz piękno. Wiązało sie
When discussing the development of the concept When discussing the develop hent of the contury ments conducted in this respect by American archiects - authors of works recognised as unique in the history of residential architecture. One of them was Arthur Brown (Rosenberg house, Tucson, Arizona, 1946) and George Fred Keck (the House of Tomorrow, 1933, and the Crystal House, 1934) (ill. 9).

After the World War lit research devoted to energycluding winter gardens in the space of the house along with it, were hindered, These concepts experienced some rebirth in the late 1960 s in the form of experiments and innovative proposals, both in Europe and the USA. The Americaexperience in this respect, which had a great effect on European solutions, were works by such W. Lumpkins, P. Van Dresser, S. Bear, D. Wright. Since the 1970 s they were developing solutions that made reference to the tradition of local bioclimatic architecture. They were characterised by unique conceptual richness and diversity, as well as functionality and economicalness, logic and beauty. It was connected not only with the effect the country but it was also based on cultural and philosophical factors ${ }^{25}$. At this point one should mention an experimental city with winter gardens by Arcosanti P. Soleri (1970) as a continuator of the concept of F. L. Wrig 

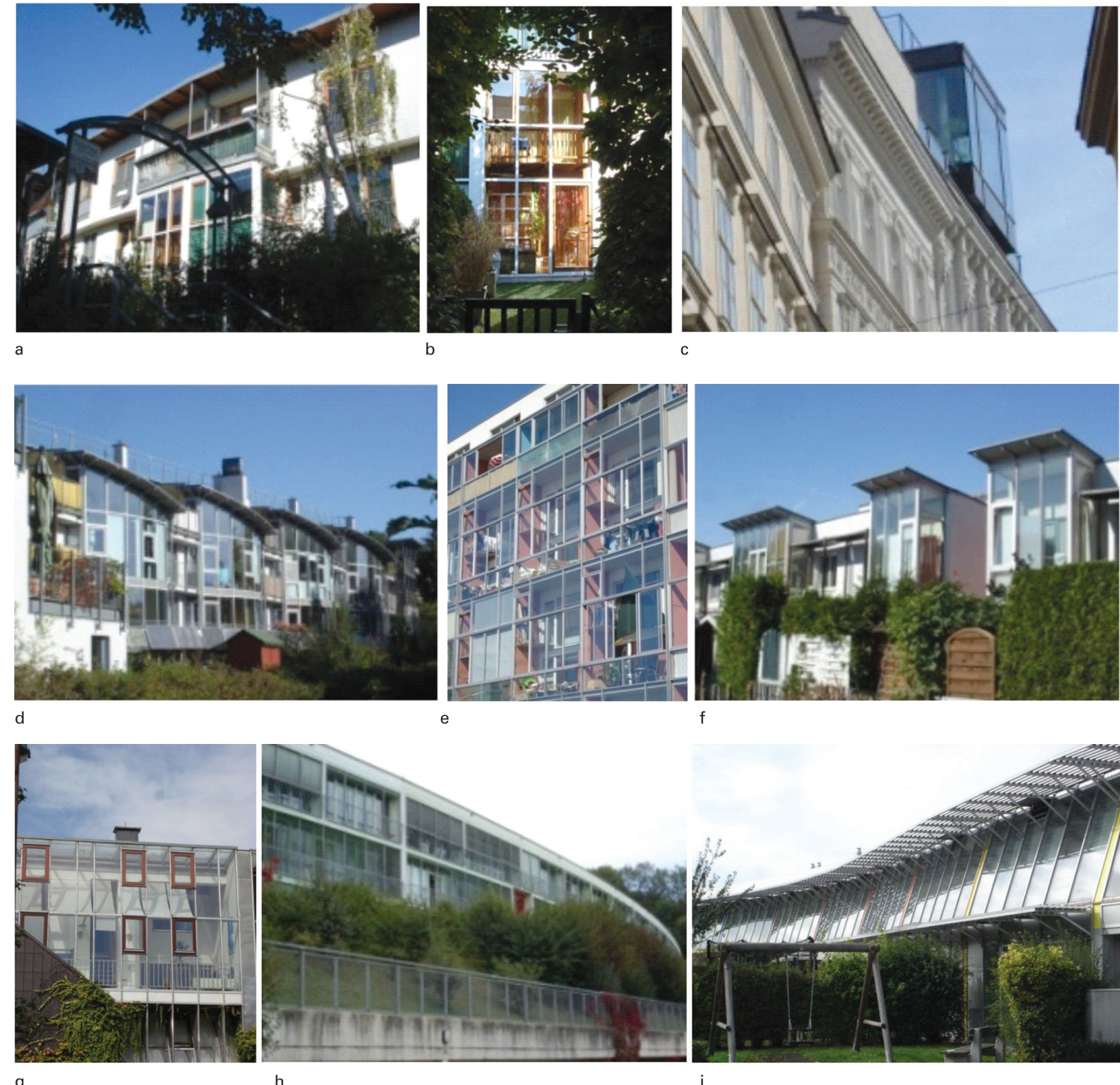

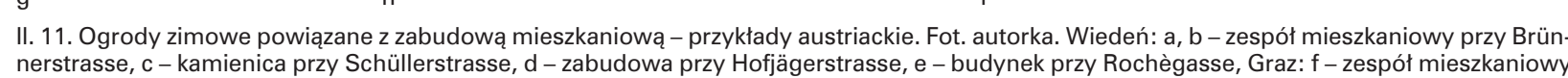

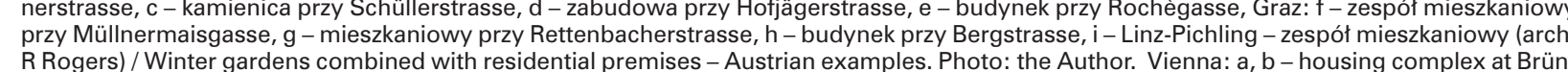
nerstrasse, $c$ - tenement house at Schüllerstrasse, $d$ - development at Hoffägerstrasse, e - building at Rochègasse, Graz: $f$-housing complex at
Müllnermaisgasse, $g$ - housing complex at Rettenbacherstrasse, $h$ - building at Bergstrasse, $i$ - Linz-Pichling - housing complex (arch. R Rogers)

to nie tylko z wpływem, zróżnicowanych na terenie kraju, czynników klimatycznych, ale też kulturalnych i filozoficznych ${ }^{25}$. Wspomnieć też należy tu o eksperymentalnym mieście z ogrodami zimowymi Arcosanti P. Soleri (1970) jako kontynuatora idei F. L. Wrighta.

4. Współczesny ogród zimowy - charakterystyka rozwiązań Zainicjowanie z końcem lat 60. XX wieku nowej kultury, zanicio jur i biocentrym stawia nowych koncepcji ekologicznych i zrównoważonych zespołów

4. Contemporary winter garden - overview

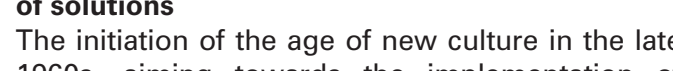
1960 s, aiming towards the implementation of a model of living based on the principles of permanent and sustainable development, eco-development, and biocentrism, became a foundation for the emergence of new concepts of ecological and nied with the renaissance of the concept of winter garden (glasshouse, conservatory, greenhouse, green room) as an important, green, climatic zone integrated with the apartment space. ill. A good preparation for a new generation to come into
being was the experimental period of $1970-1990$.
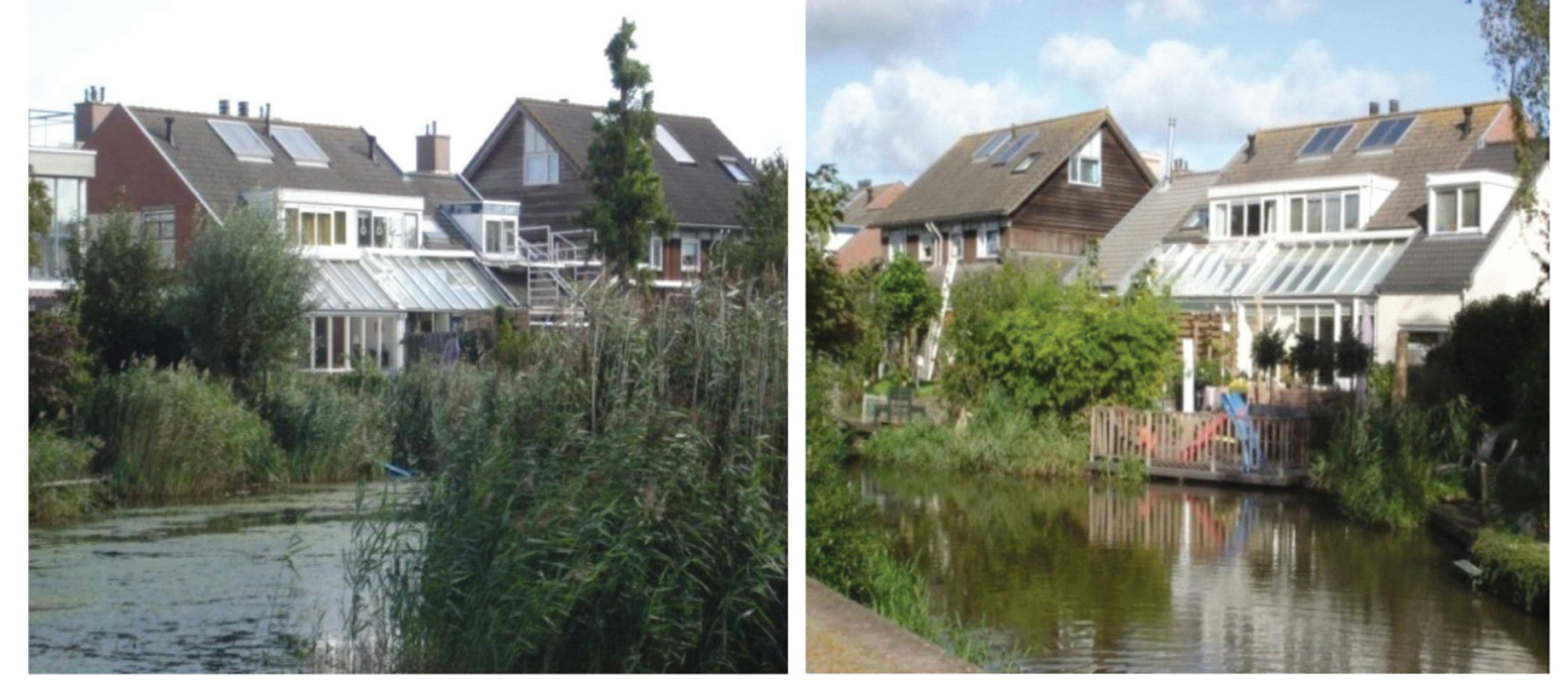

II. 12. Alphen aan den Rijn, osiedle Ecolonia (proj.L. Kroll, 1991-93) - zabudowa mieszkaniowa z ogrodami zimowymi przystosowana do pasywnego pozystiwania e energin stoncaca Fot. autorka
architecture with winter gardens, adjusted to passive harvesting of solar energy. Photo: the Autho
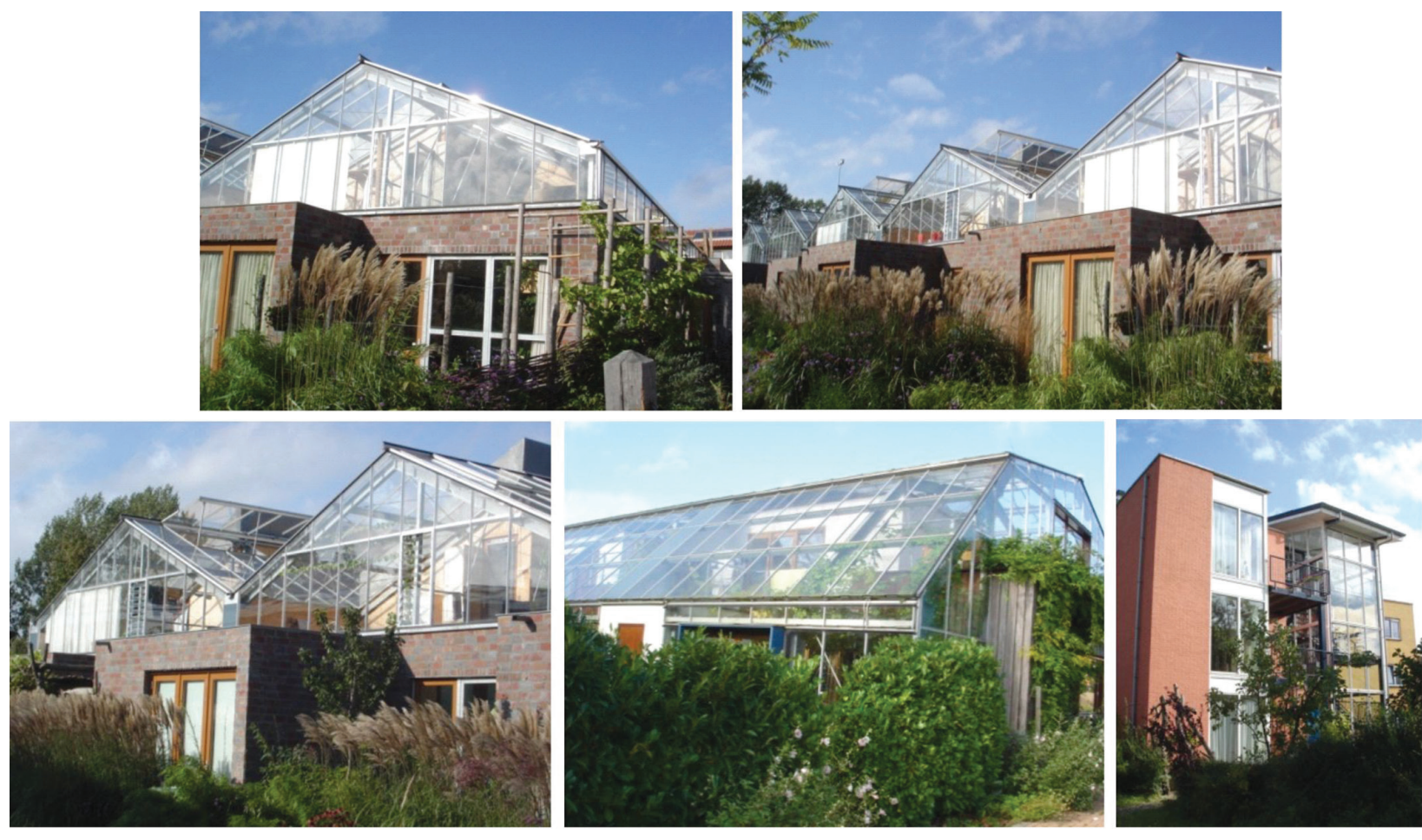

II. 13. Ogrody zimowe w domach jednorodzinnych $w$ Culemborgu, ekodzielnica EVA L L
family houses in Culemborg, EVA ecco-quarter in Lanxmeer, Holland. Photo: the Author

mieszkaniowych. Towarzyszy im renesans idei ogrodu zimowego (cieplarni, oranżerii, szklarni, zielonej izby) jako ważnej, zielonej, klimatycznej strefy zintegrowanej z przestrzenia mieszkania.

Przygotowaniem do powstania nowej generacji ogrodów zimowych był okres eksperymentalny lat 1970-1990. Pojawiły się wówczas w krajach zachodnioeuropejskich pionierskie, innowacyjne rozwiazania, m.in. we Francji, Szwajcarii (, architektura biosolarna" P. Sabady), Niemczech, Austrii i Skandynawii. Korzystano niejednokrotnie z bogatych doświadczen a wion wioni mowymi otaczającymi całą druga kondygnacje ${ }^{22}$.
Trailblazing, innovative solutions appeared then in Western European countries, e $\mathrm{g}$ in France, Switzerland ('biosolar architecture' by p. Sabady), Germany, Austria, and Scandinavia. Very frequently designers would reach to American experiencWarne 1978), with winter gardm - Natur Huset (B. entire second floor, was recognised as a model

Similarly to the present day, winter gardens were combined with small complexes of one - and mey were added to the resi-

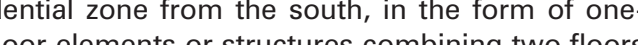
of a building, as well as in the form of gho toors (ill 10). Experiments carried out with the scheme of the International Building Exhibition 
Ogrody zimowe, podobnie jak obecnie, łączone były z niewielkimi kompleksami zabudowy mieszkaniowej jednorodzinnej i wielorodzinnej. Dodawano je od południa do strefy mieszkalnej w postaci elementów jednokondygnacyjnych lub taczacych dwie kondygnacie budynku, a takż w formie przeszklonych potaci dachowych (il. 10). Szczególne zna ich promoci dzone w ramach Miedzyarodowej Wystawy Bud (IBA, 1979-1987) w Berlinie $^{28}$.

U progu lat 90. XX wieku idea rozwoju zrównoważonego a wraz z nią zainteresowanie energooszczędnymi zasadami budowania przyniosły szczególny rozkwit szklanej architektury, która stanowi już czwartą generację tych transparentnych obiektów.

Ogrody zimowe (szklarnie, cieplarnie, hole energetyczne, zielone izby), o różnej geometrii, jako helioaktywne elementy, wpisuja się we współczesne realizacje ekologicznej zabudowy mieszkaniowej. Wprowadzane sa też w projektach sanacji zabudowy istniejacej (przykład: rewitalizacja obszarów śródmiejskich Kopenhagi). Ich szklane kubatury uzupełniane są najczęściej elementami chroniącymi wnętrza przed okresowym przegrzewaniem (osłony, zadaszenia, okapy). Realizowane są $w$ bardzo różnych skalach. Łączy się je z zabudową mieszkaniową jednorodzinną i wielorodzinną $w$ formie pojedynczych obiektów, zespołów oraz całych dzielnic miejskich (przykłady: Solar City w Linzu, Schlierberg we Fryburgu, Armada" w Hertogenbosch, Amersfoort, Ecolonia, Culombor w Holandii, Hammarby Sjöstad w Sztokholmie, Bo 01 City of Tomorrow w Malmö) (il. 11, 12, 13).

Ogrody współczesne przyjmuja też, podobnie jak w wieku $\mathrm{XIX}$, postać wielkoprzestrzennych, transparentnych, klimatycznych struktur, które kontynuują m.in. śmiate konstrukcje J. Paxtona (Crystal Palace, 1851), a także R. B. Fullera (kopuła geodezyjna, futurystyczna wizja przekrycia Manhattanu)29. Wymienic tu nalezy m.In. transparentną strukturę „Eden Project" w Kornwalii (N. Grimshaw, 2001), obiekt Biosfera 2 w Oracle w USA ${ }^{30}$, Akademie Mont-Cenis w Herne-Sodingen (arch. Jourda et Perraudin, 1999). Ważna realizacje staMinisterstwa Ochrony Srodowiska w Dessau, o formie klimatycznej struktury (arch. Sauerbruch Hutton, 1998-2005)

\section{Podsumowani}

Przedstawiona wyżej ewolucja ogrodu zimowego na przestrzeni wiekow świadczy o diugiej tradycji tączenia go z mieszkaniem i domem, a także o jego roli jako miejsca rekreacji i kontaktu z przyrodą i świattem słonecznym. Zaprezentowane przykłady ukazuja poszukiwanie $w$ architekturze rozwiazan wpisujących się w klimat i służących komfortowi człowieka, które jednocześnie posiadają wielkie walory estetyczne. Logika i piękno, a także wielkie bogactwo tych rozwiązań, które powstawały w różnych epokach i reprezentowały różne style, a także obecnie, wiąże się z prostotą ich formy podporządkowanej konstrukcji i technologii.
(IBA, 1979-1987) in Berlin were particularly important for their promotion over subsequent years ${ }^{20}$. At the threshold of the 1990s the concept of sustainable development, accompanied by the interabout a special heyday for glass architecture, which already constitutes the fourth generation of these transparent structures.

Winter gardens (greenhouses, glasshouses, energy halls, green rooms), with different geometries, as helio-active elements inscribe in contemporary duced in the projects comprising rey are also introexisting structures (example: revitalisation of the city centre areas in Copenhagen). Most frequently, their glass forms are completed with elements that protect their interiors from periodical overheating (screens, roofs, canopies). They are designed in various scales. They are frequently combined with the form of individual structures, complexes, and entire urban quarters (examples: Solar City in Linz, Schlierberg in Fryburg, 'Armada' in Hertogenbosch, Amersfoort, Ecolonia, Culemborg in Holland, Hammarby Sjöstad in Stockholm, Bo 01 City of Tomorrow in Malmo) (iil. 11, 12, 13).

The gardens of today - similarly to the gardens of transparent, climatic structures which constitute continuations of e.g. bold designs by J. Paxton (Crystal Palace, 1851), as well as by R. B. Fuller (geodesic dome, futuristic vision of a roof ove Manhattan) ${ }^{29}$. At this point one should also poin out to e.g. a transparent building 'Eden Project' in cle, USA ${ }^{30}$. Mont-Cenis Academy in Herne-Sodin gen (designed by Jourda et Perraudin, 1999). An important project is a complex of the Ministry of Environmental Protection in Dessau, in the form of a climatic structure (designed by Sauerbruch Hut-

5. Summary

Evolution of a winter garden over centuries presented herein testifies to a long tradition of combining it with an apartment or a house, as well as to its role as a place of recreation and contact with nature and sulight. Examples described in this paper demonstrate the search of architectural solutions inscribed fort of man which simultaneously exhibit great aesthetic values. Logic and beauty, as well as great richness of these solutions, which came into being in different epochs and represented different styles, as well as relevant solutions designed today, are linked with the simplicity of their form, subordinate to the

played by glass. Nowigning winter gardens was production allow for the implementation of innovative solutions in architecture. Most pursuits are directed towards achieving a smart, thermoinsulating envelope (skin) responding to climatic condtions in the surrounding area, with the durability of steel and the ability to transform sunlight an generation of glass). The diversty of contemporay architectural concepts is connected with the appli-
Szczególną rolę w kształtowaniu ogrodów zimowych pełniło szkło. Obecnie technologie jego produkcji pozwalaja na realizację nowatorskich rozwiązan w architekturze. Zmierza sie do uzyskania inteligentnej, termoizolacyinej powtoki (skóry) reagujace na warunki klimatyczne w otoczeniu, o wytzymatości stali i zdolności do transom ocil świtla dzjennego a także zacieniania wnetrz (cechy piąej generacii szkła). Różnorodność współczesnych koncepcji architektonicznych wiąże się zarówno z korzystaniem z innowacyjnych możliwo ści materiałowych (np. materiały smart), inspiracją wzoram przyrody, a także stosowaniem znanych od wieków najprostszych zasad architektury bioklimatycznej.

PRZYPISY

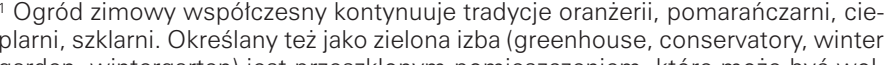
garden, wintergarten) jest przes
nostojacce lub taczone z budynkie

Szko pojawiri sie ponad 40000 lat temu. Okoto 1500 lat p. p.e. istniata w Egipcie to 750 r. . . .n.e., pozwolity na pozyskivanie jego płaskich, elementótón. Szerzej

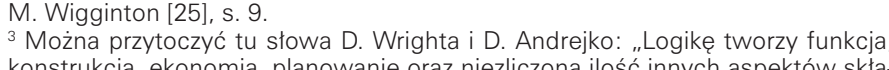

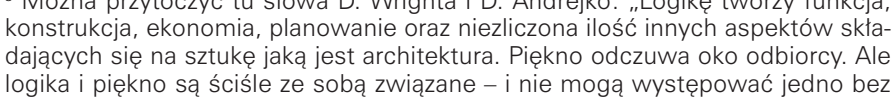
logika i piekno sá ściśle ze sobą związane - i nie mogą występować jedno bez
drugiego" Wg [26] s.7. 4 Wg Pliniusza S Starszego naibardziej znany ogród zimowy zbudowano ok. 30 ,
n.e. dla cesarza Tyberiusza. Najstarsze szklane okna odkryto w Pompejach. Ist-

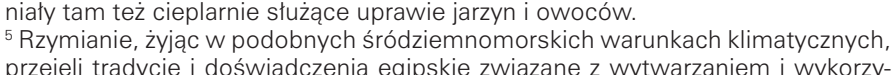
przejeli tradycjej i doświadccenia
staniem szkta w architekturze

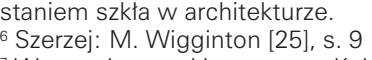

Wg przekazu w klasztorze w Kolonii ok. 1280 roku istniał kwitnący pośród śnie

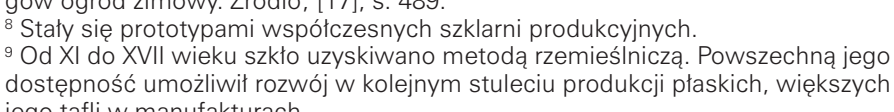
1 Zainteresowanie ich wznoszeniem $w$ tym czasie oraz $w$ kolejnych stuleciach
wiazzato sie ze szczególnie nieprzyjaznym klimatem $w$ Europie $w$ latach 1550 1 Typologie szklarni projektowanych $w$ miastach europejskich opracowa

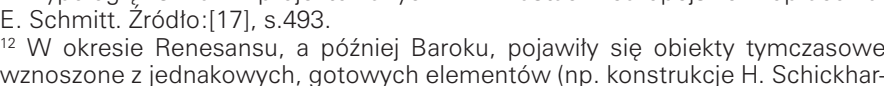
12 W okresie Renesansu, a pózniej
wznoszone z zednakowych, gotowych
dta w Stuttgarcie). Szerzej [11] s. 457 .

We Francii sa ogromne okna Sali Listranej w pałacu w Wersalu (1685).

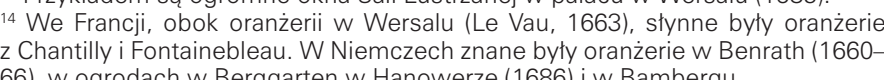

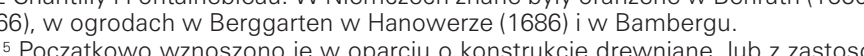
waniem scian $z$ kamienia, a takiz cegty, z pethymi dacham

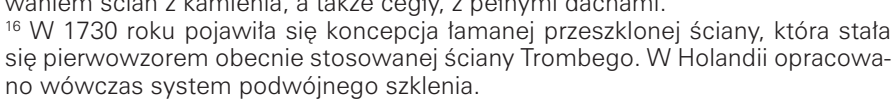

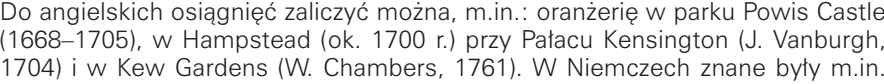
oranzieria w Kassel (J.C. Giesler, 1703-11), w Fuldzie (pocz. XVIII W.), w Gerze
$(1729-32)$ i w Poczdamie (G. W. von Knobelsdorff, 1745), a w Austrii - w ogrodach $w$ Schonburunn (N. Pacassi)
17 Wg M. Wigginton [25] s 10

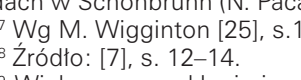

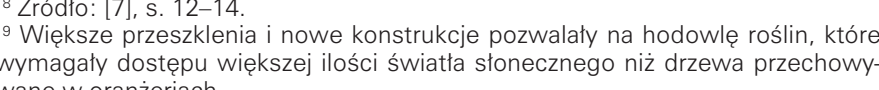
wane wo oranżeriach.
Rózinice miedzy pojeciem ogrodu zimowego (greenhouse), jako obiektu wzno-
szonego w celu uprawy roslin, a nowym typeem przeszklonej przestrzeni stuzizacej prezentacii egzotycznych gatunków (conservatory) określono w' przewod-
niku architektonicznym dla whaścicieli ziemskich "The Gentlemans' House" [4] S. 50. rchitekt tączyt ,zielone, stoneczne pokoje" przeszklonymi ścianami z saloami, a takie pokojami jadalnymi, bibliotekami oraz apartamentami waśćciciel

Stosowano konstrukcje drewniane, stalowe i żeliwn cation of innovative material-related opportunities e.g. smart materials), with getting inspired by pa-terns deriving from nature, as well as with the aparchitecture, well-known for ages.

ENDNOTES

The contemporary winter garden continues the traditions
of a conservatory, a glassroom, a greenhouse. Often referred to as a green room m (greennhouse, conservatory, winter for
fully detached, or it t can be attached to a building. it was manufactured in Egypt for decorative purposes, and
its methods, improved in ca. 750 B.C., allowed to obtain flat

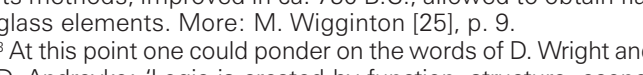
D. Andreyko: 'Logic is created by function, structure, econ-
my, planning, and a limitless number of other aspects whic ogether consititute the art of architecture. Beauty is felt by the eye of the recipient. But logic and beauty are closely connee.
ted and cannot be one without the other'. Acc. to 2261, p. 7 . According to Pliny the Elder, the best known winter garde was built in ca. 30 A.D. for Caesar Tiberius. The oldest glass
window was discovered in Pompei. There were greenhouses there, used for growing vegetables and fruit.
Romans, living in similar Mediterranean climatic con Romans, living in similar Mediterranean climatic cond
tions, took over Egyptian traditions and experiences rela
the to the manufacture of glass and using it in architecture $6 \mathrm{M}$ ore: M. Wigginton [25], p. 9 .
$7 \mathrm{It}$ is told that around 1280 in the monastery in Cologne there was a winter
urce: [17], p. 489 .
8 They became They became prototypes of contemporary production 9 greenhouses.
9 From the 11 th to the 17 th century glass was obtained
craftsmen. It became broadly available in the next century.
when the production of larger flat glass panes was developed in manufactures.
10 ent centuries was connected with the particularly unfavo-
urable climate in Europe between 1550 and 1850 . 1" The typology of greenhouses designed in European cities
was compilied by E. Schmitt. Source:[17], p. 493. ctures were erected, consisting of uniform ready-made ele-
ments (e.g. structures by H. Schickhardt in Stuttgart). More ments (e.g. ${ }^{3}$ A good example are enormous windows in the Hall of Mirrors in the Palace of Versailles (1685).
14 Resides the conservatory in Versailes,

which were famous in France were the ones in Chant were located in Benrath (1660-66), in the Berggarten gar5 Insitially, they were erected on the basis of
to ures, or using we er brick walls, with foll wooden struc作 at the time. English achievements in this e. the time. English achievements in this respect includ
e.g. the conservatory in the park of Powis Castle (1668-
1705 .

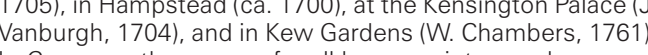
In Germany, the group of well-known winter gardens were
e.g. the conservatory in Kassel (J.C. Giesler, 1703-11), in Fulda (early 18 th century), in Gera (1729-32), and in Post-
dam (G. W. von Knobelsorff, 1745); in Austria - the gar-
dens in Schöbrunn (N. Pacassi) are worth mentioning dens in Schönbrunn (N. Pacassi) are
17 Acc. So M. Wigginton [25], p.10. 19 Larger glazed surfaces and new structures allowed to
grow plants which required more sunlight than trees kept
in conservatories. Differences between the term 'winter garden' la greenhouses as a s structure erected to cultivate plants
and the new type of a glazed s sace eimed to present species (a conservatory) were defined in th the arentititectur
handbook for landowners 'The Gentleman's House'

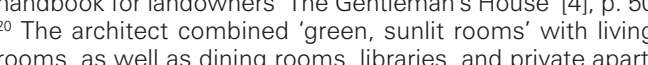
rooms, as well as dining rooms, libraries, and private
ments of house owners by means of glazed walls.
${ }^{21}$ Wooden, steel and cast iron structures were used 
22 Konstrukcje łączące szkło z żeliwem i stalą stworzyły możliwość kreowania nowych form architektonicznych. Prototypem była cieplarnia

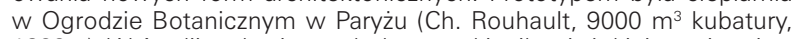
1833 r.). W Anglii stały się symbolem epoki wiktoriańskiej uważanej za złoty okres ogrodów zimowych.

23 Por. R. Bauman [2], s. 42, 43, 171

${ }_{24}$ Źródło: P. Overy [16], s. 114.

${ }^{25}$ Szerzej J. Urbanik [21], s. 41.

${ }^{26}$ Podsumowanie doświadczeń i stanu wiedzy omówionego wyżej, europejskiego okresu eksperymentalnego lat 70., związanego z systemami pasywnymi i projektowaniem ogrodów zimowych, przedstawio no w pracy K. Ohlweina (1979), M. Neddensa (1979) i A. Dütza (1981) Źródło: [26], s.8. Por. Z. Sliwiński [18].

27 Źródło: [15], s. 379.

${ }_{28}$ Szerzej:[1], s.23.

${ }^{29} \mathrm{Wg}[20]$, s. 4.

${ }^{30}$ Kopuła z aluminium i plastiku miała stanowić osłonę klimatyczną nad częścią miasta.

31 Założenie, o powierzchni $12700 \mathrm{~m}^{2}$ sfinansowane zostało przez E. P. Bassa.

\section{LITERATURA}

[1] Althaus D., Krusche P., Haus und Siedlung als Ökosysteme, DBZ 7/79

[2] Bauman R., Domy w zieleni, Warszawa, 1991.

[3] Boyce R. Keck and Keck, N. York, 1993.

[4] Butti K., Perlin J. Golden Thread. 2500 years of solar architecture and technology, New York, 1980.

[5] de Bay P., Bolton J. Garden Mania, Thames\& Hudson, London 2000

[6] Einfamilienhaus in Felsted, Dänmark, B+W 6/79.

[7] Franz J., Hanke S., Krampen M., Schempp D. Ogród zimowy, Warszawa, 2000.

[8] Haus im Weinberg, DBZ 5/78.

[9] Hix J. The Glasshouse, Pheidon Press LTD, New York, 2005.

[10] D. L., Architecture and the Environment, London, 1998.

[11] Kluckert E., European Garden Design, Ullmann/tandem Verlag $\mathrm{GmbH}, 2007$

[12] Maison Dagot, Lot-et-Garonne, L'Architecture d'Aujourd'hui, nr 209, 1980.

[13] Maison de la nature pres de Stockholm, L'Architecture D'Aujourd'hui, nr 209, 1980.

[14] Maison de la nature prés de Stockholm, L'Architecture D'Aujourd'hui, nr 209, 1980. Migge", [w:] Architektura pierwszej połowy XX wieku i jej ochrona w Gdyni i w Europie, Gdynia, 2012.

[15] Neddens M. Energieeinsparung im Bauwesen, DBZ nr 3/79.

[16] Overy P. Light, air and openness, Thames \& Hudson, Londyn, 2007.

[17] Schmitt E. Handbuch der Architektur, cz.4, A. Kröner Verlag, Stuttgart, 1906.

[18] Sliwinski S. Eine Chronologie der Solararchitectur in den USA, Detail nr 6, 2005.

[19] Trois maisons ecologiques en Finlande, L' Architecture d'Aujourd'hui, nr 209, 1980.

[20] Urban renewal Berlin, Berlin, 1991.

[21] Urbanik J. Krajobraz nowoczesnych osiedli okresu międzywojennego w Niemczech $w$ dziełach Leberechta.

[22] Wasmuths Monatshefte für Baukunst, E. Wasmuth A-G, Berlin, 1932.

[23] Wehle-Strzelecka S. Architektura słoneczna w zrównoważonym środowisku mieszkaniowym, Monografia, 312, PK, Kraków 2004.

[24] Wehle-Strzelecka S. Energia słońca w kształtowaniu środowiska mieszkaniowego - ewolucja koncepcji na przestrzeni wieków. PK, Kraków 2014.

[25] Wigginton M. Glass in Architecture, Daylight \& Architecture, Magazin by Velux, Autumn 2005.

[26] Wright D., Andrejko A. Passive Solar Architecture. Logic \& Beauty, New York, 1982.
22 Structures combining glass with cast iron and steel offered an opportunity to create new architectural forms. The prototype in this respect was a greenhouse in the Botanic Garden in Paris (Ch. Rouhault, 9000 $\mathrm{m} 3$ of space, 1833). In England they became a symbol of the Victorian era, regarded as the golden age of winter gardens.

${ }^{23}$ Cf. R. Bauman [2], p. 42, 43, 171.

24 Source: P. Overy [16], p. 114.

${ }_{25}$ More: J. Urbanik [21], p. 41.

${ }^{26}$ Summary of the experiences and knowledge of the aforementioned European experimental period of the 1970s, connected with passive systems and with designing winter gardens, was presented in the works by K. Ohlwein (1979), M. Neddens (1979), and A. Dütza (1981). Source: [26], p. 8. Cf. Z. Sliwiński [18].

27 Source: [15], p. 379.

${ }_{28}$ More:[1], s.23.

${ }^{29}$ Acc. to: [20], p. 4

30 The aluminium and plastic dome was to constitute a climatic shield over a part of the city.

${ }^{31}$ The project of the floor area of $12,700 \mathrm{~m} 2$ was financed by E. P. Bass.

\section{BIBLIOGRAPHY}

[1] Althaus D., Krusche P. Haus und Siedlung als Ökosysteme, DBZ 7/79

[2] Bauman R., Domy w zieleni, Warsaw, 1991.

[3] Boyce R. Keck and Keck, N. York, 1993.

[4] Butti K., Perlin J. Golden Thread. 2500 years of solar architecture and technology, New York, 1980.

[5] de Bay P., Bolton J. Garden Mania, Thames\& Hudson, London 2000.

[6] Einfamilienhaus in Felsted, Dänmark, B+W 6/79.

[7] Franz J., Hanke S., Krampen M., Schempp D. Ogród zimowy, Warsaw, 2000.

[8] Haus im Weinberg, DBZ 5/78.

[9] Hix J. The Glasshouse, Pheidon Press LTD, New York, 2005.

[10] D. L., Architecture and the Environment, London, 1998.

[11] Kluckert E. European Garden Design, Ullmann/tandem Verlag, $\mathrm{GmbH}, 2007$.

[12] Maison Dagot, Lot-et-Garonne, L'Architecture d'Aujourd'hui, nr 209, 1980.

[13] Maison de la nature pres de Stockholm, L'Architecture D'Aujourd'hui, nr 209, 1980

[14] Maison de la nature prés de Stockholm, L'Architecture D'Aujourd'hui, nr 209, 1980 Migge", [in:] Architektura pierwszej połowy XX wieku i jej ochrona w Gdyni i w Europie, Gdynia, 2012.

[15]Neddens M. Energieeinsparung im Bauwesen, DBZ No. 3/79.

[16] Overy P. Light, air and openness, Thames \& Hudson, Londyn, 2007.

[17] Schmitt E. Handbuch der Architektur, v.4, A. Kröner Verlag, Stuttgart, 1906.

[18] Sliwinski S. Eine Chronologie der Solararchitectur in den USA, Detail No. 6, 2005

[19] Trois maisons ecologiques en Finlande, L' Architecture d'Aujourd'hui, No. 209, 1980.

[20] Urban renewal Berlin, Berlin, 1991.

[21] Urbanik J. Krajobraz nowoczesnych osiedli okresu międzywojennego w Niemczech $w$ dziełach Leberechta.

[22] Wasmuths Monatshefte für Baukunst, E. Wasmuth A-G, Berlin, 1932

[23] Wehle-Strzelecka S. Architektura słoneczna w zrównoważonym środowisku mieszkaniowym.

Monograph, 312, Cracow University of Technology, Cracow 2004.

[24] Wehle-Strzelecka S. Energia słońca w kształtowaniu środowiska mieszkaniowego - ewolucja koncepcji na przestrzeni wieków, Cracow University of Technology, Cracow 2014.

[25] Wigginton M. Glass in Architecture, Daylight \& Architecture, Magazin by Velux, Autumn 2005.

[26] Wright D., Andrejko A. Passive Solar Architecture. Logic \& Beauty, New York, 1982. 